\title{
Seroprevalence and Associated Risk Factors of Ovine Brucellosis in South Omo Zone, Southern
} Ethiopia

\author{
Mekonnen Sorsa', Gezahegne Mamo $\mathbb{D}^{2}$, Hika Waktole ${ }^{2}$, Fufa Abunna ${ }^{2}$, Aboma Zewude ${ }^{3}$, \\ Gobena Ameni (D) ${ }^{4,5}$ \\ 'Department of Veterinary Laboratory Technology, School of Veterinary Medicine, Ambo University, Ambo, Oromia, Ethiopia; ${ }^{2}$ Department of \\ Microbiology, Immunology and Veterinary Public Health, College of Veterinary Medicine and Agriculture, Addis Ababa University, Bishoftu, Oromia, \\ Ethiopia; ${ }^{3}$ Ethiopian Public Health Institute, Addis Ababa, Ethiopia; ${ }^{4}$ Aklilu Lemma Institute of Pathobiology, Addis Ababa University, Addis Ababa, \\ Ethiopia; ${ }^{5}$ Department of Veterinary Medicine, College of Agriculture and Veterinary Medicine, United Arab Emirates University, Al Ain, United Arab \\ Emirates
}

Correspondence: Mekonnen Sorsa, Department of Veterinary Laboratory Technology, School of Veterinary Medicine, Ambo University, P.O. Box 19, Ambo, Oromia, Ethiopia, Tel +25I 9l I74488I, Email sorsa.mekonnen@yahoo.com

Background: Brucellosis is a zoonotic disease with economic and public health significance in developing countries that rely on livestock production including Ethiopia. This study intended to establish the seroprevalence and associated risk factors of ovine brucellosis.

Methods: A cross-sectional study was carried out on seroepidemiology of ovine brucellosis from January 2017 to June 2020 G.C in five districts of South Omo zone, Southern Ethiopia. A total of 1536 sera samples were collected from sheep and serially tested using modified Rose Bengal plate test, competitive enzyme-linked immunosorbent assay, and complement fixation test to detect antibodies against natural infection by Brucella species. A structured questionnaire was used to collect data from individual animals, and flocks for the analysis of the association between expounding and outcome variables. Data were analyzed using STATA version 14.0 and potential risk factors for seropositivity of brucellosis were analyzed using logistic regression.

Results: The study discovered an overall 5.40\% (95\% CI: 6.34, 14.25) and 39.74\% (95\% CI: 6.50, 6.97) seroprevalence of ovine brucellosis at individual and flock level, respectively, by a confirmatory test. Age groups, sex, flock size, district, history of abortion, and body condition were significantly associated risk factors with Brucella seropositivity $(\mathrm{p}<0.05)$.

Conclusion: To conclude, the prevalence of ovine brucellosis in the South Omo Zone was relatively high which needs integrated intervention approaches in place to curb the spread of the disease.

Keywords: brucellosis, Ethiopia, ovine, seroprevalence, South Omo

\section{Introduction}

Based on Central Statistics Authority ${ }^{1}$ Ethiopia hosts over 39.89 million sheep. Of these, $25 \%$ of sheep are inhabited in pastoral areas of the country. Despite this large population of sheep in Ethiopia, the comparative enormous resource that the country possesses and the economic return gained from this sub-sector do not seem to concur. Among the potential factors attributed to the non-coincide between huge sheep population and expected economic returns, the occurrence of diseases affecting sheep could be the major ones.

Brucellosis is one of the globally zoonotic infectious diseases, recognized as a major cause of significant economic losses in livestock due to its primary effect on the reproductive system in affected animals ${ }^{2,3}$ through the death of young stock, stillbirth, abortion, hindering efforts for improved breeding, and reduction in production. ${ }^{4}$

Ovine brucellosis is mainly caused by Brucella melitensis (B. melitensis) biovars 1, 2 or 3 andBrucella ovis (B. ovis) ${ }^{5}$ although Brucella abortus (B. abortus) may also cause clinical brucellosis in small ruminants. The disease is characterized by epididymitis, orchitis, and reduced fertility in rams and abortion, retained placenta, increased prenatal mortality 
in ewes. ${ }^{6}$ Economic losses in small ruminants stem from breeding inefficiency, loss of lambs and kids, reduced wool, meat and milk production. ${ }^{7}$

Risk factors associated with brucellosis can be categorized into management, animal, and environmental factors. The screening of new arrivals, hygiene, vaccination, size of the herd, breeding practices, and production system is management risk factors. Animal risk factors include age, breed, sex, abortion history, and milking method. The agro-ecological location of animals is categorized as an environmental factor. ${ }^{8,9}$

Most of the animals which have recovered from brucellosis spontaneously might be shedding the bacteria in urine, milk, and vaginal secretion. ${ }^{10}$ The bacterium is transmitted by sexually adult animals with predilection of the placenta and fetal fluid. ${ }^{11}$ The primary routes of transmission of ovine brucellosis are the placenta, fetal fluids and vaginal discharges excreted by infected ewes during abortion or parturition. Shedding of Brucella is also common in udder secretions and semen. ${ }^{6}$

Brucellosis poses a severe health threat to human. Human contract brucellosis by direct or indirect contact with infected animals and consumption of foods of animal origin contaminated with Brucella organism, mostly milk and milk products, especially cheese made from the unpasteurized milk of sheep and goats and rennet from infected lambs and kids. ${ }^{12}$ The disease is transmitted to man mainly by direct contact with infected livestock or through the consumption of raw or uncooked animal products. It causes a systemic infection with clinical manifestations as fever, sweats, fatigue and joint pain. ${ }^{13}$ Risk factors of human brucellosis are socio-demographic factors, contact with animals and animal products, involvement in milking, sharing water sources with animals, and assisting animals to give birth or abortion. Brucellosis is a major public health problem in Ethiopia especially among pastoral communities due to low awareness of the disease, culture of raw milk consumption and close contact with animals. ${ }^{14}$

Brucellosis in both animals and human can be diagnosed using conventional culture method, different serological tests and molecular techniques. ${ }^{15}$

There are many reports from different parts of the world that indicate sheep are more resistant to Brucella infection than goats. ${ }^{6,15}$ Most of the studies done on brucellosis of small ruminants focused more on caprine than ovine in terms of the number of animals included in the study. Furthermore, there were very limited epidemiological studies of ovine brucellosis in Ethiopia though the epidemiology of ovine brucellosis is different from that of caprine brucellosis and the presence of large size mixed sheep and goats population particularly in pastoralist areas of the country. Therefore, the aims of this study were:

- To determine the prevalence of ovine brucellosis in the South Omo Zone of Southern Ethiopia.

- To find out putative risk factors related to ovine brucellosis in the study area.

\section{Materials and Methods}

\section{Description of the Study Area}

The present study was conducted in five pastoral districts (Benatsemay, Male, Hamer, Dassenech and Gnangatom) of the South Omo zone. South Omo zone is located in the Southern Nations, Nationalities, and Peoples Region (SNNPR) of Ethiopia. The study area is located $750 \mathrm{~km}$ south of Addis Ababa (Figure 1).

The altitude of the zone is about $400 \mathrm{~m}$ above sea level. The average annual temperature ranges between $18^{\circ} \mathrm{C}$ and $32^{\circ} \mathrm{C}$ and the average annual rainfall is about $390 \mathrm{~mm}$. In the study area, rain is erratic and usually bimodal occurring from September to November and from March to May. The weather condition is characterized by a semi-arid and arid climate. The major livestock production system in the Zone is pastoral and comprises the higher livestock population of the region. ${ }^{16}$

The study animals were indigenous sheep kept under the pastoral farming system. The livestock production system is generally predominated by an extensive pastoral or agro-pastoral system in which animals are allowed to forage freely during daytime and kept in the barn during night time. All sheep in the study area with the age of 6 months and above were considered as the study animals. There is no vaccination practice against Brucella infection in all livestock species in Ethiopia yet. Livestock population in south Omo zone is estimated to be 1, 068, 120 cattle; 471, 449 sheep; 1, 230, 399 


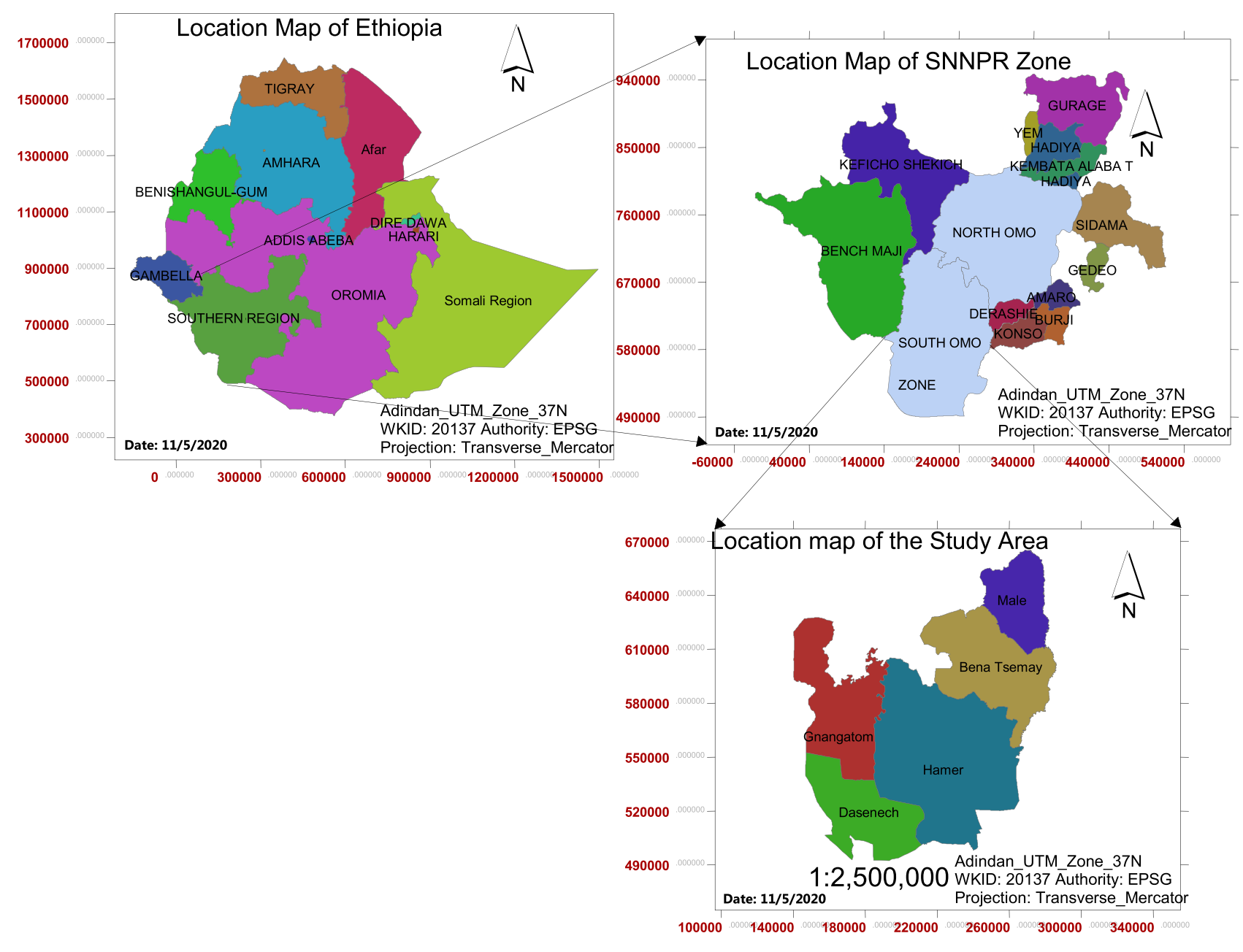

Figure I Map of the study area (South Omo zone).

goats; 90,630 donkeys and 495 camels. In Ethiopia in general and in the study area in particular there was no vaccination practice against Brucella organism in any live stock including sheep.

Pastoralists in the study area keep a diverse composite of livestock species as part of a coping mechanism for uncertainties and risks. Such conditions certainly increase the aggregation and interaction of different animals at villages, grazing fields and water points. This circumstance could facilitate the transmission of various contagious diseases among different species of livestock and human. Furthermore, the frequent migration of pastoral herds in search of pasture and water might increase the chance of contact with other potentially infected herds and exposure to diseases.

\section{Study Design and Sample Size Determination}

A cross-sectional study design was conducted from January 2017 to June 2020 in five purposely selected districts of South Omo Zone, Southern Ethiopia to determine the seroprevalence and associated risk factors of ovine brucellosis. A multistage sampling technique was used in the survey of sheep brucellosis. The pastoral Association (PA) was considered as the primary unit, the flock as secondary units and individual animals as tertiary units. Pastoral associations (PAs) within each district were randomly selected after getting lists of all PAs.

The sample size was determined using the standard procedure as described by Thrusfield ${ }^{17}$ for an infinite population. To determine the desired sample size, there were no previous reliable reports of ovine brucellosis prevalence in the selected zone. Hence, the expected prevalence of $50 \%$ was assumed within $95 \%$ confidence intervals at $5 \%$ desired 
Table I Sampling Distribution Proportion and Number of Flocks Sampled in South Omo Zone, Southern Ethiopia

\begin{tabular}{|c|c|c|c|c|c|}
\hline District & $\begin{array}{l}\text { Sheep } \\
\text { Population }\end{array}$ & $\begin{array}{l}\text { Population Proportion } \\
\text { (Rate) }\end{array}$ & $\begin{array}{l}\text { Sample Size of Each } \\
\text { District }\end{array}$ & $\begin{array}{c}\text { Total Sample } \\
\text { Size }\end{array}$ & $\begin{array}{l}\text { Number of } \\
\text { Flocks }\end{array}$ \\
\hline Bena Tsemay & $14 \mid, 350$ & $0.29982034 I I$ & $0.29982034 \mid I * 1536$ & 461 & 47 \\
\hline Male & 91,748 & 0.1946085366 & $0.1946085366 * 1536$ & 299 & 30 \\
\hline Hamer & 84,186 & 0.1785496893 & $0.1785496893 * 1536$ & 274 & 28 \\
\hline Dassenech & 105,905 & 0.2246372354 & $0.2246372354 * 1536$ & 345 & 35 \\
\hline Gnangatom & 48,260 & 0.1023652611 & $0.10236526 \mathrm{II} * 1536$ & 157 & 16 \\
\hline Total & $47 I, 449$ & $\mathbf{I}$ & $1 * 1536$ & 1536 & 156 \\
\hline
\end{tabular}

accuracy. Thus, the desired minimum sample size calculated was 384 . However, to increase the level of precision, it was inflated four times and the total sample size determined was 1536.

The required sample size (1536) determined was distributed to each district proportionally based on their sheep population (Table 1). ${ }^{18}$ Accordingly, Bena Tsemay $(n=461)$, Male $(n=299)$, Hamer $(n=274)$, Dassenech $(n=345)$, and Gnangatom $(n=157)$, sheep were sampled. The number of sheep flocks to be sampled in each district was determined by dividing the total sample size by the number of sheep to be sampled within each flock. According to the Animal Production and Veterinary Service office of each district on average each flock comprised ten sheep. Therefore, the flocks were selected for each district by dividing the distributed sample size by ten. In those flocks which had only ten animals, all sheep older than six months were sampled whereas for those flocks that had more than ten sheep the required number of samples were selected randomly from the flock. In this regard, 47 flocks from Bena Tsemay, 30 flocks from Male, 28 flocks from Hamer, 35 flocks from Dassenech, and 16 flocks from Gnangatom districts were sampled.

\section{Sample Collection}

Approximately 5-7 $\mathrm{mL}$ of whole blood samples were collected by venipuncture from the jugular vein using sterile disposable plain vacutainer tubes and needles (BD Vacutainer Systems, Plymouth, UK). The blood samples were kept at a slant position and allowed to clot at room temperature overnight. The sera were transferred into $3 \mathrm{~mL}$ Eppendorf tubes and transported on ice in the icebox to the Aklilu Lemma Institute of Pathobiology brucellosis laboratory and stored at $-20^{\circ} \mathrm{C}$ until serologically tested.

\section{Questionnaire Survey}

During the collection of blood samples, a structured questionnaire was developed and filled for each animal and flock by interviewing owners or herders using local language with the help of veterinary experts working in the district veterinary clinic to assess potential risk factors for ovine brucellosis. The questionnaire was focused on age category (Young $\leq 1$ year and Adult $\geq 1$ year), sex (Male and Female), flock size (Small $\leq 25$ sheep and Large $\geq 25$ sheep), abortion history (present and absent), stillbirth in the flock (Yes and No), history of the retained fetal membrane in the sampled animal (Yes and No), stage of abortion (Early and Late), body condition scores (Good, Medium and Poor), Production system (Pastoral, Agro-pastoral) and parity number for each animal ( 1 and $\geq 1$ ).

\section{Rose Bengal Plate Test}

The collected sera samples were tested for the presence of antibodies against the natural infection by Brucella following the protocol of the OIE. ${ }^{5}$ To improve the sensitivity of the Rose Bengal plate test (RBPT), a modified method (mRBPT) was implemented. We used three volumes $(75 \mu \mathrm{L})$ of serum and one volume of antigen $(25 \mu \mathrm{L})$ instead of an equal volume of each. Hence, mRBPT was employed for screening purpose. The RBPT antigen used was obtained from (Animal and Plant Health Agency, New Haw, Addlestone, Surrey, KT15 3NB, United Kingdom). The test was carried out in the brucellosis laboratory at Aklilu Lemma Institute of Pathobiology Addis Ababa University. Sera and antigen 
were removed from the refrigerator and kept at room temperature for 30 minutes before the test to bring to the room temperature. Briefly, the antigen and test serum were thoroughly mixed using a plastic rod, agitated for 4 minutes using a laboratory rotary shaker, and immediately read for agglutination. The results were read by examining the degree of agglutination in good light. The results were interpreted as " 0 " or negative (no agglutination), "+" (barely perceptible agglutination), “+ +" (fine agglutination and some clearing) and "+++" (course clumping, definite with clearing).

\section{Competitive ELISA}

All sera samples positive Rose Bengal plate test were further tested using competitive enzyme-linked immunosorbent assay (c-ELISA) kit (Animal and Plant Health Agency, New Haw, Addlestone, Surrey, KT15 3NB, United Kingdom). The test was carried out as per the manufacturer's instructions. Briefly, the test was conducted in 96-well polystyrene plates that are pre-coated with Brucella species lipopolysaccharide antigen, $20 \mu \mathrm{L}$ of each test serum was added to each well followed by $100 \mu \mathrm{L}$ of prepared conjugate solution. The plates were then shaken vigorously for two minutes and incubated at room temperature for 30 minutes on a rotary shaker, at 160 revolutions per minute. The plates were washed 5 times and dried by tapping on soft paper. Hydrogen peroxidase substrate and chromogen solution were prepared, added to all wells and incubated at room temperature for 20 minutes. The reaction was then being stopped using a stopping solution. Optical densities (OD) were read at $450 \mathrm{~nm}$ using a microplate reader. A positive or negative cut-off was calculated as $60 \%$ of the mean of the OD values of the four conjugate control wells. Any test sample giving an OD value equal to or below this value was regarded as being positive.

\section{Complement Fixation Test (CFT)}

All positive samples with RBPT- were further subjected to complement fixation test as a confirmatory test at the National Veterinary Institute (NVI), Bishoftu, Ethiopia. The Brucella antigen and control sera (positive and negative) used for the test were produced by Veterinary Laboratory Agency, UK, batch 16. The standardization of the antigen was made at 1:20 working dilution. The Brucella antigen, complement and 3\% sensitized sheep red blood cells were added after the test sera were serially diluted $(1: 5,1: 10,1: 20$, and $1: 40)$ in microtitre plates. Then the plates were incubated at $37^{\circ} \mathrm{C}$ for 30 minutes. The microplates were centrifuged at $2500 \mathrm{rpm}$ for 4 minutes using a sigma centrifuge and read for the result. The test was considered positive when the reading was as partial fixation (50\% haemolysis) or complete fixation (no haemolysis) with clear water supernatant at 1:10 dilution. Complete lack of fixation (complete haemolysis) was recorded as negative. The validity of the test was considered when there was complete hemolysis in negative control serum and the positive control shows inhibition of hemolysis. Subsequently, interpreted as a serum with strong reaction, more than $75 \%$ fixation of complement at a dilution of 1:5 and at least with 50\% fixation of complement at a dilution of 1:10 and dilution of $1: 20$ were classified as positive. ${ }^{19}$

\section{Data Management and Analysis}

The data gathered through the questionnaire survey and laboratory analysis were stored in a Microsoft Excel spreadsheet and analyzed using STATA version 14.0 for Windows (Stata Corp. College Station, USA). During the statistical analysis, for all the risk factors, the first level of each independent variable was used as a reference category. A sheep was considered as positive for brucellosis provided that positive results were recorded for serial tests (mRBPT, C-ELISA, and CFT). A flock having at least one seropositive sheep was considered as positive. Seroprevalence was computed by dividing the total number of sheep tested positive by confirmatory test CFT by the total number of sheep tested. Correspondingly, flock level seroprevalence was calculated by dividing the number of flocks with at least one positive sheep by confirmatory test (CFT) by the total number of flocks tested. Logistic regression analysis was used to assess the association between seropositivity and explanatory variables. The odds ratio was computed to compare the degree of association among potential risk factors with seropositivity for brucellosis. A Confidence interval (CI) of $95 \%$ and $5 \%$ cut-off value was set for significance. ${ }^{20}$ For all analyses, a p-value of less than 0.05 was taken as statistically significant. 
Table 2 Seroprevalence of Ovine Brucellosis in Five Districts of South Omo Zone, Southern Ethiopia

\begin{tabular}{|l|c|l|l|l|l|l|l|}
\hline Districts & $\begin{array}{c}\text { Number of } \\
\text { Tested Sheep }\end{array}$ & $\begin{array}{l}\text { mRBPT } \\
\text { Positive }\end{array}$ & $\mathbf{9 5 \% ~ C I}$ & $\begin{array}{l}\text { C-ELISA } \\
\text { Positive }\end{array}$ & $\mathbf{9 5 \%}$ CI & CFT Positive & 95\% CI \\
\hline $\begin{array}{l}\text { I. Bena } \\
\text { Tsemay }\end{array}$ & $46 I$ & $19(4.12 \%)$ & $0.45,4.68$ & $17(3.69 \%)$ & $0.50,2.55$ & $17(3.69 \%)$ & $0.52,3.00$ \\
\hline 2. Male & 299 & $12(4.01 \%)$ & $0.38,3.29$ & $10(3.34 \%)$ & $0.80,4.20$ & $10(3.34 \%)$ & $0.75,4.85$ \\
\hline 3. Hamer & 274 & $20(7.30 \%)$ & $2.16,5.04$ & $18(6.57 \%)$ & $1.05,3.45$ & $13(4.74 \%)$ & $1.78,3.90$ \\
\hline 4. Dassenech & 345 & $40(11.59 \%)$ & $4.24,5.13$ & $35(10.14 \%)$ & $7.50,12.35$ & $34(9.85 \%)$ & $8.12,14.40$ \\
\hline 5. Gnangatom & 157 & $14(8.91 \%)$ & $8.06,12.20$ & $12(7.64 \%)$ & $5.40,9.80$ & $9(5.73 \%)$ & $11.50,17.20$ \\
\hline Total & 1536 & $105(6.84 \%)$ & $\mathbf{4 . 2 0 , 6 . 4 0}$ & $\mathbf{9 2 ( 5 . 9 8 \% )}$ & $\mathbf{5 . 1 0 , 7 . 4 0}$ & $\mathbf{8 3}(\mathbf{5 . 4 0 \% )}$ & $\mathbf{6 . 3 4 , 1 4 . 2 5}$ \\
\hline
\end{tabular}

\section{Ethical Consideration}

Ethical clearance for this study was obtained from College of Veterinary Medicine and Agriculture of Addis Ababa University by Animal Research Ethical and Review committee with certificate Ref.No:VM/ERC/10/03/12/2020. Before sample collection, the owners of the animals were informed with the objectives of the study and verbal consent had been obtained to take blood sample from the sheep and this issue was included in the ethical clearance obtained. During sample collection the sheep were treated with best practice of veterinary care.

\section{Results}

\section{Overall Prevalence}

Out of 1536 sheep sera samples tested, $6.84 \%$ (105/1536; 95\% CI: 4.20, 6.40), 5.98\% (92/1536; 95\% CI: 5.10, 7.40), and $5.40 \%(83 / 1536 ; 95 \%$ CI: $6.34,14.25)$ were found to be positive for brucellosis by mRBPT, C-ELISA, and CFT tests, respectively, at individual animal level (Table 2). Ovine brucellosis was detected by CFT in $39.74 \%(62 / 156$; $95 \%$ CI: $6.50,6.97$ ) of the flocks tested (Table 3).

Regarding distribution of ovine seroprevalence among the districts, the highest seroprevalence was recorded in Gnangatom district 100\% (16/16; 95\% CI: 15.58, 18.30) followed by Dassenech 62.86\% (22/35; 95\% CI: 3.06, 5.45) and Hamer $32.14 \%$ (9/28; 95\% CI: 11.43, 14.42), respectively, in descending order (Table 3).

In the present study, ovine brucellosis at PAs (the smallest administrative units) showed 3 of 5 (60\%) PAs from Bena Tsemay, 2 of 5 (40\%) PAs from Male, 4 of 5 (80\%) PAs from Hamer, 5 of 5 (100\%) PAs from Dassenech, and 5 of 5 (100\%) PAs from Gnangatom districts contain at least one seropositive sheep for brucellosis.

Table 3 Flock Level Seroprevalence of Ovine Brucellosis in South Omo Zone, Southern Ethiopia

\begin{tabular}{|l|c|c|c|}
\hline Districts & $\begin{array}{c}\text { Number of Flocks } \\
\text { Tested }\end{array}$ & $\begin{array}{c}\text { CFT } \\
\text { Positive }\end{array}$ & $\mathbf{9 5 \% ~ C l ~}$ \\
\hline I. Bena Tsemay & 47 & $13(27.66 \%)$ & $22.50,24.05$ \\
\hline 2. Male & 30 & $2(6.67 \%)$ & $7.65,13.70$ \\
\hline 3. Hamer & 28 & $9(32.14 \%)$ & $11.43,14.42$ \\
\hline 4. Dassenech & 35 & $22(62.86 \%)$ & $3.06,5.45$ \\
\hline 5. Gnangatom & 16 & $16(100 \%)$ & $15.58,18.30$ \\
\hline Total & 156 & $\mathbf{6 2 ( 3 9 . 7 4 \% )}$ & $\mathbf{6 . 5 0 , 6 . 9 7}$ \\
\hline
\end{tabular}

Abbreviations: $\mathrm{CFT}$, complement fixation test; $\mathrm{Cl}$, confidence interval. 


\section{Risk Factors Analysis}

The results of univariate and multivariate logistic regression analysis of individual animal level showed that district, sex, age, body condition, history of abortion, history of retained fetal membrane, parity, flock size, and production system had a statistically significant association with Brucella seropositivity $(\mathrm{p}<0.05)$.

Univariate logistic regression analysis (Table 4) showed that ewes were 3.5 times more likely to contract brucellosis as compared to rams $(\mathrm{P}=0.000)$. Adult sheep were found to be 2 times more likely to be infected by Brucella Organism than young ones $(\mathrm{P}=0.003)$. Sheep in large flocks were 2.5 times more likely to be infected by brucellosis as compared to medium and small flock size $(\mathrm{P}=0.0041)$. Ewes with a history of abortion were 4 times more likely to contract brucellosis than ewes without a history of abortion $(\mathrm{P}=0.000)$. Furthermore, sheep with poor body condition score were found to be 3 times more likely to have brucellosis as compared to those with good body condition ( $\mathrm{P}=$ $0.007)$.

\section{Discussion}

Brucellosis is an important zoonosis that causes abortion in naturally infected small ruminants and is of great public health concern in many countries of the world. ${ }^{21}$ In Ethiopia, proximity and close contact between humans and animals are very common especially in pastoral settings due to the entire livelihood of the pastoralist community rely on their livestock. This study provides updates on the prevalence of brucellosis in sheep in the South Omo Zone of Southern Ethiopia.

The current study used serially RBPT as screening and C-ELISA and CFT as assenting tests. Employing serial tests is recommended to maximize the accuracy of test results. RBPT is an exceedingly sensitive test while C-ELISA and CFT are very specific and used as confirmatory tests for detection of brucellosis. ${ }^{6}$ The combination of these serial tests in this study could therefore maximize the accuracy of the findings in excluding false-positive serological reactors in RBT which could be due to cross-reactions with Smooth Lipopolysaccharide (S-LPS) antigens of other bacteria closely related to Brucella. Variations in the test results of C-ELISA and CFT are due to the differences in sensitivity of the tests. The C-ELISA test is more sensitive as compared to CFT for the diagnosis of brucellosis. However, both tests have similar specificities of $99.9 \% .{ }^{19}$ RBPT is more suitable for detecting the IgG1 and IgM typically produced during acute brucellosis. On the other hand, ELISA and CFT are more suitable for detecting IgG which becomes dominant in chronic cases of brucellosis. In our results out of 105 sera, samples positive with RBPT, $12.38 \%$ and $20.95 \%$ were seronegative with C-ELISA and CFT, respectively. This implies that RBPT suffers from false-positive reactions. The results of the present study were in agreement with those theories and out of 1536 sheep tested for brucellosis $6.84 \%(105 / 1536)$, 5.98\% (92/1536), and 5.40\% (83/1536) were positive for brucellosis with RBPT, C-ELISA and CFT tests, respectively.

This piece of work appears to be the first extensive study of its kind on the prevalence of ovine brucellosis in the study area in terms of the sample size and coverage area. The present study was carried out to estimate seroprevalence and potential risk factors for acquiring ovine brucellosis. The overall seroprevalence of $5.40 \%$ (95\% CI: 6.34, 14.25) was recorded at the individual animal level. This shows that ovine brucellosis is endemic in Ethiopia at a relatively higher level.

The seroprevalence result of the present study $(5.40 \%)$ is nearly following the findings of Benkirane et al ${ }^{21}$ who reported 5.6\% from Afar and Somali regional states, Tsehay et $\mathrm{al}^{22}$ observed 5.42\% from Oromia and Somali regional states, Shimeles and Andualem ${ }^{23}$ detected 5.87\% from Amhara regional state, Ethiopia. The finding of the current study was also in close agreement with previous reports from other countries: $5.2 \%$ in Nigeria by ${ }^{2}$ and others. ${ }^{7,24}$ However, the result was higher than the result reported by Aregawi et $\mathrm{al}^{25} 0.6 \%$ and by Mihreteab et $\mathrm{al}^{26} 1.56 \%$.

Contrary to our finding, higher ovine seroprevalences of brucellosis were recorded $6.70 \%$ by Nigatu et al ${ }^{27}$ in Ethiopia, $10 \%$ by Muhammad et $\mathrm{l}^{28}$ elsewhere. This variation may be due to differences in age, sex, production system, sample size, test methods used for diagnosis, flock composition, agro-climate.

Of the 1536 sheep sampled for this study, 30.01\% (461/1536) were from the BenaTsemay district, $19.47 \%$ (299/1536) were from the Male district, 17.84\% (274/1536) were from Hamer district, 22.46\% (345/1536) were from Dassenech district, and 10.22\% (157/1536) were from Gnangatom district. Sheep from Dassenech and Gnangatom districts had the 
Table 4 Association of Ovine Brucellosis with Various Risk Factors in South Omo Zone, Southern, Ethiopia

\begin{tabular}{|c|c|c|c|c|c|c|c|}
\hline \multirow[b]{2}{*}{ Variables } & \multirow[b]{2}{*}{ Alternatives } & \multicolumn{4}{|c|}{ Univariate Logistic Regression Analysis } & \multicolumn{2}{|c|}{$\begin{array}{l}\text { Multivariate Logistic } \\
\text { Regression Analysis }\end{array}$} \\
\hline & & $\begin{array}{l}\text { Number } \\
\text { of Sheep } \\
\text { Tested }\end{array}$ & $\begin{array}{l}\text { CFT } \\
\text { Positive }\end{array}$ & OR $(95 \% \mathrm{Cl})$ & P-value & OR $(95 \% \mathrm{Cl})$ & P-value \\
\hline \multirow[t]{5}{*}{ Districts } & Bena Tsemay & 461 & $17(3.69 \%)$ & Reference & & & \\
\hline & Male & 299 & $10(3.34 \%)$ & $0.1(0.25,2.12)$ & 0.120 & & \\
\hline & Hamer & 274 & $13(4.74 \%)$ & $0.6(0.75,3.10)$ & 0.060 & & \\
\hline & Dassenech & 345 & 34 (9.85\%) & $3.2(1.98,14.58)$ & 0.001 & $2(3.56,17.50)$ & 0.025 \\
\hline & Gnangatom & 157 & $9(5.73 \%)$ & $2.6(1.48,5.32)$ & 0.002 & & \\
\hline \multirow[t]{2}{*}{ Sex } & Male & 549 & $5(0.91 \%)$ & Reference & & & \\
\hline & Female & 987 & 78 (7.90\%) & $3.5(2.45,17.50)$ & 0.000 & $3(1.55,6.78)$ & 0.000 \\
\hline \multirow[t]{2}{*}{ Age } & Young (<1 Year) & 390 & $10(2.56 \%)$ & Reference & & & \\
\hline & Adult (>I Year) & 1146 & $73(6.37 \%)$ & $2(4.80,29.50)$ & 0.003 & $1.7(9.40,12.50)$ & 0.011 \\
\hline \multirow[t]{3}{*}{ Flock size } & Small ( $\leq 25$ sheep) & 730 & $24(3.28 \%)$ & Reference & & & \\
\hline & Medium ( 26 to 49 sheep) & 579 & $25(4.32 \%)$ & I.I $(2.78,11.34)$ & 0.041 & & \\
\hline & Large ( $\geq 50$ sheep) & 227 & $34(14.98 \%)$ & $2.50(3.55,11.90)$ & 0.001 & $1.8(2.05,14.05)$ & 0.000 \\
\hline \multirow{2}{*}{$\begin{array}{l}\text { Production } \\
\text { system }\end{array}$} & Agropastoral & 275 & II (4.0\%) & Reference & & & \\
\hline & Pastoral & $|26|$ & 72 (5.7।\%) & $3(1.95,3.57)$ & 0.014 & $3(1.75,7.00)$ & 0.032 \\
\hline \multirow{2}{*}{$\begin{array}{l}\text { History of } \\
\text { abortion }\end{array}$} & No & 410 & 8 (1.95\%) & Reference & & & \\
\hline & Yes & 577 & $70(12.13 \%)$ & $4(5.65,34.90)$ & 0.000 & $4(2.00,7.90)$ & 0.000 \\
\hline \multirow{2}{*}{$\begin{array}{l}\text { Stage of } \\
\text { abortion }\end{array}$} & Early & 185 & $16(8.65 \%)$ & Reference & & & \\
\hline & Late & 392 & $54(13.77 \%)$ & $1.9(1.78,4.92)$ & 0.013 & $1.2(1.08,2.69)$ & 0.022 \\
\hline $\begin{array}{l}\text { History of } \\
\text { RFM }\end{array}$ & $\begin{array}{l}\text { No } \\
\text { Yes }\end{array}$ & $\begin{array}{l}432 \\
555\end{array}$ & $\begin{array}{l}13(3.00 \%) \\
65(11.71 \%)\end{array}$ & $\begin{array}{l}\text { Reference } \\
0.1(0.45,11.10)\end{array}$ & 0.071 & & \\
\hline \multirow[t]{2}{*}{ Still birth } & No & 333 & $30(9.0 \%)$ & Reference & & & \\
\hline & Yes & 654 & 71 (10.86\%) & $1.3(0.78,19.80)$ & 0.089 & & \\
\hline \multirow{3}{*}{$\begin{array}{l}\text { Body } \\
\text { condition } \\
\text { score }\end{array}$} & Good & 490 & II (2.24\%) & Reference & & & \\
\hline & Medium & 540 & $9(1.67 \%)$ & $0.12(0.35,2.57)$ & 0.044 & & \\
\hline & Poor & 506 & 63 (I2.45\%) & $3.1(1.25,9.85)$ & 0.007 & $1.7(2.60,11.32)$ & 0.005 \\
\hline \multirow{2}{*}{$\begin{array}{l}\text { Parity } \\
\text { number }\end{array}$} & One & 372 & $22(5.82 \%)$ & Reference & & & \\
\hline & More than one & 615 & 56 (9.10\%) & $0.5(0.98,3.95)$ & 0.130 & & \\
\hline
\end{tabular}

Abbreviations: $\mathrm{Cl}$, confidence interval; OR, odds ratio; RFM, retained fetal membrane.

highest seroprevalence of $9.85 \%$ (95\% CI: 1.04, 4.58) and 5.73\% (95\% CI: 1.48, 13.32), respectively, with statistically significant difference $(\mathrm{P}<0.05)$ between the districts. But there was no statistical significance difference observed between the remaining districts BenaTsemay, Hamer and Male even though high seroprevalence was recorded for each. Univariable logistic regression analysis showed that the odds of acquiring brucellosis in the Dassenech district is about 3 
times higher as compared to sheep in Bena Tsemay districts $(\mathrm{P}=0.001)$ and a significant difference was also evident in the final model.

This significant difference in Dassenech and Gnangatom districts as compared to others could be attributed to higher flocks accumulation on the Omo river basin in search of water and grass which increases contact among flocks that may be infected by brucellosis. In addition, the relative higher seroprevalence observed in the Gnangatom district could also be related to contact or interface between sheep flocks and wildlife at Omo National Park even though the status of brucellosis in wildlife in the area is unknown. Furthermore, the lack of adequate veterinary infrastructure and services in the area as the aforementioned districts are the remotest area in the country might have contributed to the relative higher seroprevalence and the widespread of the disease in the districts.

Males comprised 35.75\% (549/1536) of sheep sampled and females comprised 64.25\% (987/1536) of sheep sampled for this study. A higher rate of seroprevalence of $7.90 \%(95 \%$ CI: $2.45,17.50)$ was recorded in females as compared to males at $0.91 \%$. The difference was statistically significant $(\mathrm{P}=0.000)$. Univariable logistic regression analysis demonstrated that the odds of acquiring brucellosis in female sheep is about 3.5 times higher as compared to the male sheep $(\mathrm{P}=0.000)$. Similarly, a significant difference was also evident in the final model. The result of the present study is in line with the previous report of Shimeles and $\mathrm{Alemu}^{29}$ in the smallholder production system, significantly higher $(\mathrm{P}<$ $0.001)$ seroprevalence was observed in female $(8.21 \%, 95 \%$ CI: $5.2-11.8)$ than in male sheep $(3.01 \%$, $95 \%$ CI: $2.41-$ 4.34). Similarly, a statistically significant difference $(\mathrm{P}<0.05)$ was also observed among male and female sheep. ${ }^{28}$ This implied that it is a fact that male animals are less susceptible to Brucella infection, due to the absence of erythritol, and the absence of physiological stress-causing factors like pregnancy in males.

Contrary to our finding, previous reports from Ethiopia verified that higher seropositivity was observed in males over females though no statistically significant $(\mathrm{P}>0.05)$ difference was found between male and female sheep. ${ }^{25,30}$

The age of the sheep was grouped into two categories: young $(<1$ Year) $(n=390)$, and adult $(>1$ Year $)(n=1146)$. Among the age categories, the higher seroprevalence of $6.37 \%$ was observed for those sheep above one year old, and $2.56 \%$ seroprevalence was recorded for those below 1-year-old. Both univariate and multivariate logistic regression analysis showed a statistically significant association between ovine seropositivity and age categories $(\mathrm{P}=0.003)$. Furthermore, the odds of brucellosis exposure in aged sheep (adult) were about 2 times higher than that of young sheep.

Similar to the present finding, significantly higher seroprevalence was reported in sexually matured (adult) than in young sheep from the same country Ethiopia. ${ }^{6,14,30-33}$ This phenomenon could be due to two important conditions. The first reason is that younger animals are more resistant to infection and frequently clear an established infection. The second reason may be related to the fact that sex hormones and erythritol which stimulate the growth and multiplication of Brucella organisms tend to increase in concentration with age and sexual maturity.

The present study covered a total of 156 flocks of sheep from five districts of the South Omo zone. The number of flocks sampled was distributed to each district based on the sheep population. Accordingly, 30.13\% (47/156) flocks were from Bena Tsemay district, 19.23\% (30/156) flocks were from Male district, 17.95\% (28/156) flocks were from Hamer district, $22.44 \%$ (35/156) flocks were from Dassenech district, and 10.25\% (16/156) flocks of sheep were from Gnangatom district. The overall flock level seroprevalence of ovine brucellosis was found to be $39.74 \%$ (95\% CI: $6.50,6.97)$. The highest seroprevalence of $100 \%(16 / 16)$ was recorded in Gnangatom district followed by $62.86 \%(22 / 35)$ in Dassenech district, and 32.14\% (9/28) in Hamer district. The least flock level seroprevalence of $6.67 \%$ of ovine brucellosis was detected in the Male district. The possible explanation for very high flock level seroprevalence in Gnangatom and Dassenech districts as compared to others could be related to the larger flock density observed in the two districts which might increase the chance of spread of the disease among the livestock population. On the other hand, the least flock level prevalence observed in the Male district might be correlated with smaller flock density, sheep are confined at home, limited movement of flocks in search for feed and water since the production system in the district is more of agro-pastoral.

In the current study, we classified flock size into three groups as small flock size (for a flock comprising $\leq 25$ sheep), medium flock size (for a flock comprising 26 to 49 sheep), and large flock size (for a flock comprising $\geq 50$ sheep). The current study indicated a strong statistically significant difference between seropositivity of ovine brucellosis and flock size. Higher seroprevalence was recorded in large flock size with a rate of $14.98 \%$ compared to the medium and small 
flock size with a rate of $4.32 \%$ and $3.28 \%$, respectively. The univariate logistic regression test verified that the odds of acquiring brucellosis for sheep in large flock size is 2.5 times higher $(95 \% \mathrm{CI}: 3.55,11.90, \mathrm{P}=0.001)$ than those in small flock size. A similar result was obtained by multivariate logistic regression analysis.

The present study was following the previous investigations of ${ }^{29,34}$ those who reported that seroprevalence of ovine brucellosis was significantly different among the flock size categories (small, medium and large) and seroprevalence increases with flock size in Ethiopia. Another previous study was also evidenced that lower seroprevalence in small flocks compared to medium-sized and large-sized flocks ${ }^{35}$ from other countries elsewhere.

Out of 987 female sheep, 75.38\% (577/987) had a history of abortion. Of 577 sheep with a history of abortion, $12.13 \%$ (95\% CI: $5.65,34.90)$ were found to be positive for antibody against natural infection by Brucella. Out of 410 sheep without a history of abortion, 1.95\% (8/410) were detected seropositive. The seroprevalence of brucellosis in female sheep was statistically significant with a history of abortion $(\mathrm{P}<0.05)$. Regarding the association between seropositivity and history of abortion, the result of the current study is consistent with other reports. ${ }^{36,37}$ Previous studies from Ethiopia reported that there was a significant association $(\mathrm{P}<0.05)$ between seropositivity to brucellosis and history of previous abortion in sheep. ${ }^{38}$

Abortion is the most predominant symptom of brucellosis in naturally infected sheep. The animals commonly abort only once, but reinvasion of the uterus and shedding of organisms can occur during subsequent pregnancies. Some infected animals carry the pregnancy to term and shed the organism. ${ }^{7,36}$ It can be concluded that abortion of infected animals is important for public health. ${ }^{21}$

This study revealed a higher seroprevalence of $11.71 \%(65 / 555)$ in sheep with a history of the retained fetal membrane than those without a history of retained fetal membrane 3.0\% (13/432) even though there was no statistically significant difference $(\mathrm{P}>0.05)$ observed. This result is consistent with other reports. ${ }^{37}$ This indicates that abortions or stillbirths and retained placenta are typical outcomes of brucellosis. ${ }^{6}$

Higher prevalence $(10.86 \%, 95 \%$ CI: $0.78,19.80)$ was recorded in sheep with stillbirth while the prevalence of $9 \%$ was observed in sheep without stillbirth though no statistically significant differences. Various authors reported that stillbirth, abortion, infertility, and the birth of weak offspring are recorded as the common clinical signs of brucellosis in natural hosts. ${ }^{36,39}$

The body condition of the animals was one of the risk factors considered in the present study. Accordingly, the highest prevalence $(12.45 \%, 95 \%$ CI: $1.25,9.85)$ was observed in sheep with poor body condition score while the lowest prevalence $(1.67 \%, 95 \%$ CI: $0.35,2.57)$ was observed in sheep with medium body condition score.

In the present study, higher seroprevalence of brucellosis $(9.10 \%)$ was recorded in ewes with more than one parity than those with only one parity (5.82\%). However, there was no statistical significance difference between different numbers of parties. This result is closely consistent with other reports from Ethiopia. ${ }^{37,40}$ The increase in seroprevalence recorded with the increasing number of parity numbers could be related to the increased age of the animals that increases the chance of exposure to brucellosis.

\section{Conclusions}

In conclusion, ovine brucellosis is endemic at a moderately high level in the study area. Age, sex, flock size, history of abortion and retained fetal membrane, body condition, and parity number are among the major putative risk factors associated with the seropositivity of ovine brucellosis. Furthermore, sheep may act as a potential public health hazard for the spread of brucellosis to humans as well as other animals due to their stay in a close association with the human community and other animals, during movement in search for feed and water, and congestion at pasture and water points. Hence, it warrants the formulation of effective control measures, routine screening, and vaccination along with the public awareness campaign about the transmission of the disease between animals and from animals to humans to reduce the zoonotic risk among the pastoralists.

\section{Abbreviations}

CFT, complement fixation test; C-ELISA, competitive enzyme linked immunosorbent assay; CI, confidence interval; ELISA, enzyme linked immunosorbent assay; NVI, National Veterinary Institute; OD, optical densities; OIE, Office 
International des Epizooties; OPD, O-phenylenediamine dihydrochloride; OR, odds ratio; mRBPT, modified Rose Bengal plate test; PA, Pastoral Association; S-LPS, smooth lipopolysaccharide; SNNPR, Southern Nations, Nationalities, and Peoples Region.

\section{Data Sharing Statement}

All data generated and analysed during this study were included in the manuscript.

\section{Acknowledgments}

The authors are grateful to Professor Gobena Ameni for logistics allocation for the research including establishment of standardized biosafety level III Brucella laboratory. We would also like to extend our thanks to Addis Ababa University College of Veterinary Medicine and Agriculture and Ambo University for supporting this research work.

\section{Author Contributions}

All authors made a significant contribution to the work reported, whether that is in the conception, study design, execution, acquisition of data, analysis and interpretation, or in all these areas; took part in drafting, revising or critically reviewing the article; gave final approval of the version to be published; have agreed on the journal to which the article has been submitted; and agree to be accountable for all aspects of the work.

\section{Disclosure}

The authors declared that they have no conflicts of interest for this work.

\section{References}

1. Central Statistical Agency (CSA). Federal Democratic Republic of Ethiopia Central Statistical Agency agricultural sample survey 2019/20, Volume II Report on Livestock and Livestock Characteristics. Statistical Bulletin 587. Addis Ababa, Ethiopia; 2020:1-222. Available from: https://www. statsethiopia.gov.et/wp-content/uploads/2020. Accessed January 13, 2022.

2. Bertu WJ, Ajogi I, Bale JO, Kwaga JP, Ocholi RA. Sero-epidemiology of brucellosis in small ruminants in Plateau State, Nigeria. Afr J Microbiol Res. 2010;4:1935-1938.

3. Ehizibolo DD, Gusi AM, Ehizibolo PO, Mbuk E, Ocholi RA. Serologic prevalence of brucellosis in horse stables in two northern states of Nigeria. J Equine Sci. 2011;22:17-19. doi:10.1294/jes.22.17

4. Maadi H, Moharamnejad M, Haghi M. Prevalence of brucellosis in cattle. 2015; 475-489. Available from: https://www.oie.int/fileadmin/Home/eng/ . Accessed January 13, 2022.

5. OIE. Caprine and Ovine Brucellosis (Excluding Brucella Ovis Infection). In Manual of Standard for Diagnostic Test and Vaccine. 4th ed. Paris; 2015: 475-489. Available from: https://www.oie.int/fileadmin/Home/eng/. Accessed January 13, 2022.

6. Radostits OM, Gay CC, Blood CD, Hinchcliff KW. Veterinary medicine, textbook of the disease of cattle, sheep, pigs, goats and horses. 9th ed. New York: W.B. Saunders Company Ltd; 2007: 867-882. Available from: https://www.amazon.com/Veterinary-Medicine-textbook-diseasesRadostits/dp/0702027774. Accessed January 13, 2022.

7. Lone IM, Baba MA, Shah MM, Iqbal A, Sakina A. Seroprevalence of brucellosis in sheep of organized and unorganized sector of Kashmir valley. Vet World. 2013;6:530-533. doi:10.5455/vetworld

8. Ogugua AJ, Akinseye VO, Ayoola MC, Stack J, Babalola CSI. Risk factors associated with brucellosis among slaughtered cattle: epidemiological insight from two metropolitan abattoirs in south western Nigeria. Asian Pac J Trop Dis. 2016;5:747-753. 10.1016/S2222-1808(15)60925-2.

9. Zeng J, Duoji C, Yuan Z, Yuzhen S, Fan W, Tian L. Seroprevalence and risk factors for bovine brucellosis in 2015 domestic Yaks (Bos grunniens) in Tibet, China. Trop Anim Health Pro. 2017;49:1339-1344. doi:10.1007/s11250-017-1331-7

10. Winn W, Allen S, Janda W, Koneman W. Koneman's Color Atlas and Textbook of Diagnostic Microbiology. 6th ed. New York, NY, USA: Lippincott Williams and Wilkins; 2006: 482-491. Available from: https://www.scirp.org//reference/ReferencesPapers.aspx?. Accessed January 13, 2022.

11. Seyyed-Gholizadeh S, Sadeghi MH, Hashempour A, Mirahmadi E. Investigation of brucellosis in cattle and sheep in Urmia-Iran. YYU Vet Faculty Dergici. 2013;24:133-134.

12. Seleem MN, Boyle SM, Sriranganathan N. Brucellosis: a reemerging zoonosis. Vet Microbiol. 2010;140(3-4):392-398. doi:10.1016/j. vetmic.2009.06.021

13. Genene R, Mekonen D, Yamueh L, Tilahun H, Gebreyohanes A. Human brucellosis in traditional pastoral communities in Ethiopia. Intr J Trop Med. 2009;4:59-64.

14. Negash E, Shimelis S, Beyene D. Seroprevalence of small ruminant brucellosis and its public health awareness in selected sites of Dire Dawa region, Eastern Ethiopia. J Vet Med Animal Health. 2012;4:61-66.

15. Acha PN, Szyfres B. Zoonoses and Communicable Diseases Common to Man and Animals. 3rd ed. Washington, DC. 2001; 40-66. Available from: https://www.paho.org/hq/dmdocuments/. Accessed January 13, 2022.

16. Central Statistical Agency(CSA). Agricultural Sample Survey. Statistical Bull. 2017;2:1-126. Available from: http://www.sciepub.com/reference/ 267721. Accessed January 13, 2022. 
17. Thrusfield M. Veterinary Epidemiology. 3rd ed. Oxford: Blackwell Science; 2007: 251-281. Available from: https:/dvmbooks.weebly.com/uploads/ 2/2/3/6/22365786/1. Accessed January 13, 2022.

18. Kothari CR. Research Methodology Methods and Techniques. 2nd ed. New Delhi: New Age International Ltd; 2014: 156. Available from: https:// www.academia.edu/33779875/. Accessed January 13, 2022.

19. Godfroid J, Nielsen K, Saegerman C. Diagnosis of brucellosis in livestock and wildlife. Croat Med J. 2010;51:296-305. doi:10.3325/ cmj.2010.51.296

20. Wagner B, Gardner I, Cameron A, Doherr MG. Statistical analysis of data from surveys, monitoring, and surveillance systems. In: Salman MD, editor. Animal Disease Surveillance and Survey Systems: Methods and Applications. Ames, IA, USA: Blackwell Publishing; $2003: 67-86$. doi:10.1002/9780470344866.

21. Benkirane A, Essamkaoui S, Idrissi EL, Lucchese L, Natale A. A serosurvey of major infectious causes of abortion in small ruminants in Morocco. Vet Ital. 2015;51:25-30. doi:10.12834/VetIt.389.1814.1

22. Tsehay H, Getachew G, Morka A, Tadesse B, Eyob H. Seroprevalence of brucellosis in small ruminants in pastoral areas of Oromia and Somali regional states, Ethiopia. J Vet Med Animal Health. 2014;6:289-294. doi:10.5897/JVMAH2014.0331

23. Shimeles AA, Andualem YD. Comparative seroepidemiological study of brucellosis in sheep under smallholder farming and governmental breeding ranches of Central and North East Ethiopia. J Vet Med. 2018. doi:10.1155/2018/7239156

24. Jamal G, Mahmoudreza R, Abbasi-Doulatshahi E, et al. Sero-epidemiological survey of brucellosis in small ruminants in Hamedan province, Iran. J Adv Vet Anim Res. 2016;3:399-405. doi:10.5455/javar.2016.c179

25. Aregawi G, Daniel H, Berihun A. Seroprevalence of Ovine Brucellosis in a sheep export farm, Ethiopia. Global Vet. 2013;11:325-328. doi:10.5829/idosi.gv.2013.11.3.75118

26. Mihreteab B, Mohammed H, Tefera M, Tolosa T. Small ruminant brucellosis and community perception in Jijiga District, Somali Regional State, Eastern Ethiopia. Trop Anim Health Prod. 2011;43:893-898. doi:10.1007/s11250-011-9781-9

27. Nigatu S, Deneke M, Kassa T. Sero-prevalence of brucellosis in sheep and goat destined for slaughter in selected export abattoirs, Ethiopia. Afr J Basic Appl Sci. 2014;6:82-86. doi:10.5829/idosi.ajbas.2014.6.3.8638

28. Muhammad AH, Rahmatullah R, Muhammad A, et al. Seroprevalence of brucellosis in sheep and humans in District Kohat, Pakistan. Adv Anim Vet Sci. 2014;2:516-523. doi:10.14737/journal.aavs/2014/2.9.516.523

29. Shimeles A, Alemu A. Sheep Brucellosis: Prevalence and Zoonotic Impacts of Sheep Brucellosis: Study on Sheep Brucellosis in Selected Districts of Amhara Regional State, Ethiopia. Germany: Lap Lambert Academic publishing; 2012:1-80.

30. Ashenafi F, Teshale S, Ejeta G, Fikru R, Laikemariam Y. Distribution of brucellosis among small ruminants in the pastoral region of Afar, eastern Ethiopia. Rev Sci Tech. 2007;26:731-739. doi:10.20506/rst.26.3.1781

31. Quinn PJ, Carter ME, Markey BK, Carter GR. Clinical Veterinary Microbiology. London: Mosby Elsevier; 2004.

32. Yosef D, Nardos T. Sero-prevalence of ovine brucellosis in and around Debre Birhan region of Ethiopia. Ind J Comp Microbiol Immunol Infect Dis. 2010;31:44-47.

33. Adugna W, Sisay T, Keskes S. Sero-prevalence of small ruminants' Brucellosis in four districts of Afar National Regional State, Northeast Ethiopia. $J$ Vet Med Anim Health. 2013;5:358-364. doi:10.5897/JVMAH2013.0231

34. Gebremedhin EZ. Seroepidemiology of Ovine Brucellosis in East and West Shewa Zones of Oromia Regional State, Central Ethiopia. J Veterinar Sci Technol. 2015;6:265. doi:10.4172/2157-7579

35. Chavez JM, Career E, Cháirez FG, Aréchiga F, Bañuelos VR, Tórtora JL. Possible risk factors for serological prevalence of Brucella ovis in Zacatecas, Mexico. Rev Mex Cienc Pecu. 2013;4:61-74.

36. Samadi A, Ababneh MK, Giadinis NK, Lafi SQ. Ovine and Caprine Brucellosis (Brucella melitensis) in aborted animals in Jordanian sheep and goat flocks. Vet Med Int. 2010;2010:1-7. doi:10.4061/2010/458695

37. Tegegn AH, Feleke A, Adugna W, Melaku SK. Small ruminant brucellosis and public health awareness in two districts of Afar Region, Ethiopia. $J$ Veterinar Sci Technol. 2016;7:335. doi:10.4172/2157-7579.1000335

38. Gumaa MM, Osman HM, Omer MM, El Sanousi EM, Godfroid J. Seroprevalence of brucellosis in sheep and isolation of Brucella abortus biovar 6 in Kassala State, Eastern Sudan. Revue Scientifique Et Technique (International Office of Epizootics). 2014;33:957-965. doi:10.20506/rst.33.3.2333

39. Sonawane GG, Tripathi S, Dubey SC. Sero-incidence of brucellosis in small ruminants of semiarid Rajasthan. Indian J Anim Sci. $2011 ; 81: 327-329$.

40. Edao BM, Ameni G, Assefa Z, Berg S, Whatmore AM, Wood JL. Brucellosis in ruminants and pastoralists in Borena, Southern Ethiopia. PLoS Negl Trop Dis. 2020;14:e0008461. doi:10.1371/journal.pntd.0008461

\section{Publish your work in this journal}

Infection and Drug Resistance is an international, peer-reviewed open-access journal that focuses on the optimal treatment of infection (bacterial, fungal and viral) and the development and institution of preventive strategies to minimize the development and spread of resistance. The journal is specifically concerned with the epidemiology of antibiotic resistance and the mechanisms of resistance development and diffusion in both hospitals and the community. The manuscript management system is completely online and includes a very quick and fair peer-review system, which is all easy to use. Visit http://www.dovepress.com/testimonials.php to read real quotes from published authors.

Submit your manuscript here: https://www.dovepress.com/infection-and-drug-resistance-journal 